[日農医誌 48巻 1 号 13～20頁 1999. 5]

\title{
原著：
}

\section{臭化メチルを用いたハウス内の土䉴薰蒸作業に おける職業曝露と健康影響に関する研究}

\author{
甲 田茂 樹*，大原 啓 志*
}

臭化メチルを用いたハウス内の土壤薰蒸作業に従事する農業者の臭化メチル曝露に伴う 健康障害を予防するために, 薰蒸作業前後の臭化メチルのモニタリングと個人曝露測定, 薰蒸方法や保護具の使用，自覚症状等に関するアンケート調査を実施した。

八ウス内の環境モニタリング結果によると, 八ウス開放時でも $1,000 \mathrm{ppm}$ を超える極め て高い臭化メチル濃度が観測された。ハウス開放に従事した農業者への個人曝露測定結果 では $57 \mathrm{ppm}$ と $25 \mathrm{ppm}$ と, 許容濃度を遥かに超えていた。高知県内 6 地区の園芸農家で臭 化メチルを用いた土壌薰蒸を行っている農業者164名のアンケート調査結果から, 8 割近 くがハウス全面薰蒸方式を採用しており, 行政の指導している使用量を遥かに超える臭化 メチルを使用しており，9割以上が薰蒸後 5 日以内にハウスを開放していた。さらに，臭 化メチル高濃度曝露を防ぐ防毒マスクや防除衣の着用を行っているものはわずかに $10 \%$ 程 度であった。薰蒸作業後の自覚症状では, 眼や呼吸器などの刺激症状を訴える農業者が 2 〜 $6 \%$ 程度認められた。

現状の臭化メチルを用いた薰蒸作業では短時間で高濃度の臭化メチルに農業者が曝露す ることが懸念された。臭化メチルによる健康障害を予防するためにも, 臭化メチルの有害 性や健康障害に関する教育や安全な使用量の徹底や作業方法の訓練等を実施することが重 要である。

\section{(1)臭化メチル (2)土壌薰蒸 (3)個人曝露 (4)環境モニタリング (5)施設園芸}

\section{I はじあにに}

臭化メチルは1987年のモントリオール議定書 でオゾン層破壊物質として指定され，その生産 と使用が2005年には必要最低限のものを除いて 全廃する方向で現在検討されている化学物質で ある。わが国では園芸農業を中心として臭化メ チルが土壤薰蒸剛として幅広く用いられてお り，1992年ないしは1993年の統計でみると米 国，イタリアに次いで世界第三位の使用量と なっている。

\footnotetext{
* † 783-8505 高知県南国市岡豊町小蓮 高知医科大学公衆衛生学教室

（受付：1999年 2 月 8 日）
}

高知県は全産業に占める農業者の割合が高 く, 行政が把握している数值だけでみても基幹 的農業従事者は約 6 万人に上り, 勤労者に占め る比率は約 $13 \%$ にたるる では施設園芸が盛んであるため，八ウスでの土 潩薰蒸凨として臭化メチルを使用する頻度が多 い。国内の臭化メチルの生産量に対する高知県 への出荷量をみても，毎年約13〜14\%を推移 し, 高知県での臭化メチルの需要がいかに多い かがわかる。

臭化メチルは，わが国の労働安全衛生法体系 （主には特定化学物質等障害予防規則）の中で 規制されている有害化学物質であり，産業保健

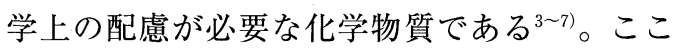


表 1. 臭化メチルに関する許容濃度について

\begin{tabular}{ll}
\hline ACGIH*1 $^{*}$ & 1ppm (TLV-TWA*2) \\
NIOSH*3 $^{*}$ & reduced exposure to lowest feasible concentration \\
& as Cartinogens \\
& IDLH*4 250ppm \\
& $20 \mathrm{ppm}(\mathrm{C} * 6$, skin $)$ \\
\hline
\end{tabular}

*1:American Conference of Governmental Industrial Hygienists

ACGIH は1997年に許容濃度を $5 \mathrm{ppm}$ から 1ppm 一改正

$* 2: 8$ 時間時間加重平均の許容濃度

* 3 :National Institute for Occupational Safety and Health

*4:immediately dangerous for life and health concentration

*5:米国労働安全衛生法

*6:天井值としての許容濃度

数年, 高知県でも臭化メチル中毒の事例が報告 されており，農業の現場における臭化メチル使 用状況や健康影響について検討する必要性が指 摘されてきた。産業保健における臭化メチルの 規制については，管理濃度が $5 \mathrm{ppm}$ と決めら れており ${ }^{3,8)}$, 個人曝露の際の許容濃度につい ては表 1 に示したような基準が国際的に提案さ れている9,10)。

本研究では, 高知県内の園芸農家の協力を得 て, 臭化メチル使用状況の実態を把握し, 作業 形態や使用濃度, 使用量と個人曝露の程度を検 討することで, 臭化メチルへの高濃度曝露によ る健康障害を防ぐための基礎資料を得たいと考 えた。このことは, 産業保健学的にも, 環境保 健学的にも, 極めて重要な資料を提示してくれ るものと考える。

\section{II. 研究対象及び方法}

高知県の園芸農家における臭化メチル使用状 況の実態を把握し，作業形態や使用濃度，使用 量と個人曝露の程度を検討するために, 高知県 内で頻繁に行われている薰蒸方法であるハウス 内全面薰蒸に注目し, ハウス内の気中臭化メチ ル濃度のモニタリングと薰蒸作業前後での農業 者への個人曝露濃度の測定を1996年 9 月に実施 した。なお，今回の環境モニタリング及び個人
曝露測定に協力してもらった園芸農家の薰蒸作 業に用いられた臭化メチルの使用量は10アール 当たり約 $45 \mathrm{~kg}$ である。

臭化メチルの環境モニタリングは, 赤外線を 用いた光音響方式による定量ガス分析装置

(Bruel \& Kjaer 社製マルチガスモニタ1302及 び1303型）と臭化メチル専用光学フィルター (UA-0987型), 専用アプリケーションソフト （7620型）を搭載したコンピュータによって実 施した。今回の測定では，ハウス外にシステム を設置し, 約 $50 \mathrm{~m}$ の長さのテフロンチューブ を用いてハウス内の測定点（立位呼吸域である $1.5 \mathrm{~m}$ と座位呼吸域の $0.5 \mathrm{~m}$ の 2 点）より約 140 $\mathrm{ml}$ の気体試料を採取し, 光音響方式を用いて 臭化メチルの気中濃度を測定することで, 環境 モニタリングを実施した。なお，サンプリング の間隔は 1 時間毎と設定した。今回のシステム の測定制度の校正にあたっては, 純窒素を用い たゼロ点校正と臭化メチルのある濃度近辺での 1 点校正を実施した。その結果, 測定精度とし ては0.2〜2,000ppm までは直線的な関係が保 たれていると考えて良い。一点校正には，2.29 $\mathrm{ppm}$ の臭化メチルを用いて校正を行った。な お, 測定に際しては水蒸気の補正を常時行った 上で，環境モニタリングを実施した。

臭化メチルの個人曝露測定については，活性 
炭.管（SKC 製，第 1 層 $100 \mathrm{mg} ，$ 第 2 層 $50 \mathrm{mg}$ ） を農業者の襟に装着し, 携帯用吸引ポンプ (Dupont 製, ALPHA 2) で呼吸域の臭化メ チルを吸引捕集 $(100 \mathrm{ml} / \mathrm{min})$ し, 二硫化炭素 $2 \mathrm{ml}$ で脱着した後にガスクロマトグラフ

(Hewlett Packard 製, HP-5980, シリーズ II）によって分析した。カラムは DB-1（J\& $\mathrm{W}$ 製，内径 $0.58 \mathrm{~mm}$ ，長さ $30 \mathrm{~m} ）$ を用い，カラ 厶温度, 注入口温度及び検出器温度はそれぞれ $40^{\circ} \mathrm{C}, 150^{\circ} \mathrm{C}, 200^{\circ} \mathrm{C}$ と，キャリアーガスには ヘリウム $(12 \mathrm{ml} / \mathrm{min})$, 検出器にはFIDを用 いた。個人曝露測定は, 臭化メチルへの曝露を 考慮し，臭化メチルを散布する時，薰蒸後に八 ウスを開放する時，ハウス開放の翌日にハウス 内に入って行うパイプ配管作業の三つの作業に 注目して実施した。

次に, 高知県内の園芸農家の臭化メチル薰蒸 の実態を把握し, 臭化メチル曝露に伴う健康影 響などについて検討するために，ハウス園芸を 行っている県内 6 地区の農家から, 臭化メチル による薰蒸作業を行っている農業者に協力して もらい, 地区の農業改良普及センターの生活改 良普及員を通じて, 留置法にてアンケート調査 を実施した。ただし，この対象者はランダムサ ンプリングによるものではない。調査項目に は, 臭化メチル薰蒸方法, 使用量, 防御方法,
薰蒸後数日の自覚症状に関する項目を採用し た。なお，アンケート調查の実施は，臭化メチ ルによる土壤薫蒸が概ね完了する1996年の夏か ら秋の時期にかけて行い, 調查票の集計及び解 析はSPSS $8.0 \mathrm{~J}$ for Windows を用いて行っ た。

\section{III. 研 究 結 果}

\section{1. ハウス全面薫蒸作業時の臭化メチルの環境 モニタリングと個人曝露について}

ハウス内の全面薰蒸に伴う臭化メチルの気中 濃度の推移をモニタリングした結果を図 1 （臭 化メチル濃度は対数变換済み) に示した。臭化 メチルは空気よりその比重が重いため, 臭化メ チルを散布して数時間の間は座位の方が高 く, 5,000ppm を超えていたが，しばらくする と2, 200 2, 300ppm のレベルに推移し，その 後は測定点の高低によらず両者はほぼ同じ値を 示すようになった。その後はハウス開放まで ゆっくりと減少していき，ハウス開放時には 1,100〜 1, 200ppm 前後となっていた。ハウス 開放後に一挙に低下した臭化メチル濃度も一端 $200 \mathrm{ppm}$ まで再上昇しており，その後にゆっく りと減少していった。

農業者の個人曝露について測定した結果を表 2 に示したが，臭化メチル散布時には直接散布

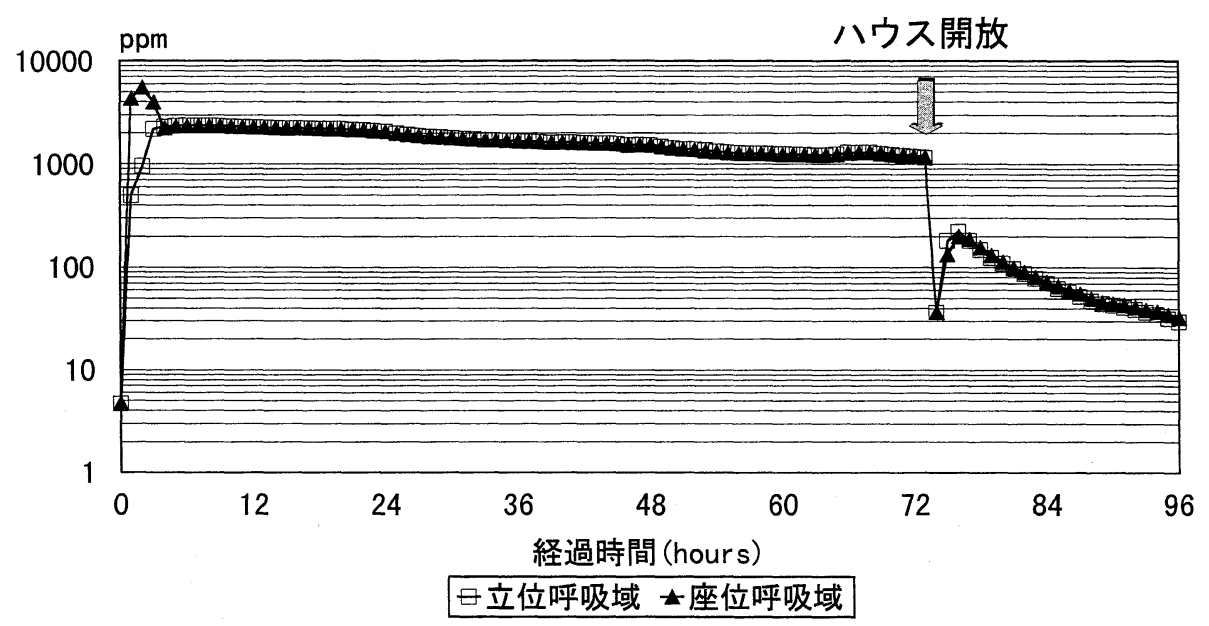

図 1.八ウス内の臭化メチル濃度の環境モニタリング

(ハウス内全面薰蒸, 臭化メチル濃度は対数変換済み) 
表 2. 臭化メチルの個人曝露測定結果について

\begin{tabular}{lllll}
\hline 臭化メチル散布時 & A 氏夫 & $0.1 \mathrm{ppm}$ 以下 & A 氏妻 & $0.1 \mathrm{ppm}$ 以下 \\
& B氏夫 & $0.1 \mathrm{ppm}$ 以下 & B氏妻 & $0.1 \mathrm{ppm}$ 以下 \\
ハウス解放時 & A氏夫 & $57 \mathrm{ppm}$ & A 氏妻 & $0.1 \mathrm{ppm}$ 以下 \\
& B氏夫 & $25 \mathrm{ppm}$ & B氏妻 & $0.1 \mathrm{ppm}$ 以下 \\
パイプ配管時 & A 氏夫 & $0.1 \mathrm{ppm}$ 以下 & A 氏妻 & $0.1 \mathrm{ppm}$ 以下 \\
(午前・午後各々 $)$ & B氏夫 & $0.1 \mathrm{ppm}$ 以下 & B氏妻 & $0.1 \mathrm{ppm}$ 以下 \\
\hline
\end{tabular}

作業に携わった夫 2 名とハウスの外で待機して いた妻 2 名（合計 4 名）の個人曝露濃度はいず れも $0.1 \mathrm{ppm}$ 以下であった。ハウス開放作業自 体は約20分程度で終了するが，直接八ウスの開 放作業に携わった夫 2 名については $57 \mathrm{ppm}$ と $25 \mathrm{ppm}$ の臭化メチルに曝露していた。ハウス 開放の翌日のパイプの配管作業時の個人曝露は いずれも0.1ppm 以下であった。ハウス内の環 境モニタリングで観察する限りにおいては, 気 中に臭化メチルが数十 ppm 存在していたが, 個人曝露測定では検出できなかった。

\section{2. 臭化メチル薫蒸農家に対するアンケート調}

\section{査結果について}

高知県内 6 地区の農業改良普及センターの生 活改良普及員を通じてアンケート調査できたも のは全員で165名であり，このうち，性別が明 らかで調査年度に薰蒸作業を実施した162名を 分析対象とした。分析対象とした 162 名の性別 の内訳は男性134（82.7\%)，女性28（17.3\%） であり, 平均年齢は 47.0 歳（標準偏差10.6歳） であった。

臭化メチル薰蒸作業に関する回答を表 3 にま とめたが, 全面薰蒸を採用しているものが 8 割 近くを占め, その使用量は, 全面薰蒸及びマル チで10アールあたり $40 \mathrm{~kg}$ 前後であったが, 併 用した 4 事例はかなり多い使用量となってい た。薰蒸後のハウス開放までの日数をみると, 全体の $90 \%$ 以上が 5 日以内に開放しており，そ の平均日数は全面薫蒸で約 3.5 日, マルチ薰蒸 で5.4日と両者に違いを認めた。保護具の使用 状況についてみていくと, もっとも高い比率が 帽子であり，ついで手袋や長靴などの一般的な
ハウス園芸で用いられるものであり，臭化メチ ルに対する効果的な保護具である防除衣や防毒 マスクの使用状況はきわめて低かった。

薰蒸作業後の自覚症状の有無についてみる と，物忘れがあるが最も高くなっていたが，眼 がしみるとか気分が悪くなる，吐き気がする， 咳がでるなどの急性曝露の症状が 2 〜 \% 程度 あり，薰蒸作業時に高い濃度の臭化メチルを一 時的に曝露した可能性が示唆された。また，ア ンケートに回答した者のうちで「眼がしみる」 「めまいがする」「気分が悪くなる」「吐き気が する」「咳がでる」などを訴える70歳をこえる 高齢の農業者が 1 名認められた。この作業者は 10アールあたりの臭化メチルの使用量は回答者 の平均の 3 倍近くに達し, 明らかに臭化メチル の過剩使用であり, 薫蒸方法にも問題のあるこ とが推測された。

薰蒸作業と健康影響に関する農業者の意識を 調査したところ, 薰蒸作業は健康に悪影響を与 えているといつも考えている者が6名 (3.6\%)， 時々を含めると 26 名 $(15.8 \%)$ であり, 過去の 薰蒸作業後に体調を崩して医療機関を受診した 者も 1 名存在していた。

\section{N. 考察}

今回のハウス内の臭化メチルの環境モニタリ ング結果から, 八ウス内の臭化メチル濃度は 3 日目で $1,000 \mathrm{ppm}$ 程度はあるために, 早い時期 でのハウス開放は農業者に高濃度の臭化メチル 曝露をもたらす可能性がある。今回の個人曝露 測定結果でもハウス開放にあたった農業者は 各々 $57 \mathrm{ppm}$ と $25 \mathrm{ppm}$ の臭化メチルを曝露して 
表 3.アンケート調査結果について（n=162）

\begin{tabular}{|c|c|c|c|}
\hline \multicolumn{3}{|l|}{ 臭化メチル薰蒸歴 } & $17.4 \pm 10.2$ 年 \\
\hline \multicolumn{4}{|c|}{ 臭化メチル薰蒸方法及び使用量（10アール当たり使用量） } \\
\hline \multicolumn{2}{|l|}{ 全面薰蒸 } & $128(79.0 \%)$ & $38.3 \pm 15.8 \mathrm{~kg} / 10 \mathrm{a}$ \\
\hline \multicolumn{2}{|l|}{ マルチ薫蒸 } & $30(18.5)$ & $47.0 \pm 73.8$ \\
\hline \multicolumn{2}{|l|}{ 両方 } & $4(2.5)$ & $49.6 \pm 8.7$ \\
\hline \multirow{7}{*}{\multicolumn{2}{|c|}{ 薰蒸後、ハウス開放までの日数 }} & $1-2$ 日 & $3(1.9 \%)$ \\
\hline & & 3 日 & $87(53.7)$ \\
\hline & & 4 日 & $46(28.4)$ \\
\hline & & 5 日 & $13(8.0)$ \\
\hline & & $6-7$ 日 & $10(6.2)$ \\
\hline & & $8-14$ 日 & $3(1.9)$ \\
\hline & & 30 日 & $1(0.6)$ \\
\hline \multirow{3}{*}{\multicolumn{2}{|c|}{ ハウス開放までの平均日数 }} & 全面薰蒸 & $3.5 \pm 0.8$ 日 \\
\hline & & マルチ薰蒸 & $5.4 \pm 2.4$ \\
\hline & & 両方 & $3.5 \pm 0.5$ \\
\hline \multirow{5}{*}{\multicolumn{2}{|c|}{ 保護具の使用について }} & 防除衣 & $6(3.7 \%)$ \\
\hline & & 帽子 & $67(41.4)$ \\
\hline & & 長靴 & $28(17.3)$ \\
\hline & & 防毒マスク & $21(13.0)$ \\
\hline & & 手袋 & $29(17.9)$ \\
\hline \multicolumn{4}{|c|}{ 薰蒸後数日の自覚症状の有無 } \\
\hline 眼がしみる & $9(5.6 \%)$ & 物忘れがある & $18(11.1 \%)$ \\
\hline めまいがする & $1(0.6)$ & \multicolumn{2}{|c|}{ 耳鳴り、聞こえにくい 6 (3.7) } \\
\hline 気分が悪くなる & $8(4.9)$ & \multicolumn{2}{|l|}{ 腹痛がする } \\
\hline 吐き気がする & $4(2.5)$ & \multicolumn{2}{|l|}{ 下痢をする } \\
\hline 咳がでる & $5(3.1)$ & \multicolumn{2}{|l|}{ 気が滅入る } \\
\hline 手足がしびれる & $4(2.5)$ & \multicolumn{2}{|l|}{ 歩きづらい } \\
\hline \multicolumn{4}{|c|}{ 言葉が話しづらい 4 (2.5) } \\
\hline \multicolumn{4}{|c|}{ 薰蒸作業と健康への不安 いつも/いつも+時々 $6 / 26(3.6 / 15.8 \%)$} \\
\hline \multicolumn{4}{|c|}{ 過去に薰蒸後に体調を崩して医療機関受診経験女り } \\
\hline
\end{tabular}

おり, ACGIH の許容濃度である $1 \mathrm{ppm}$ を遥か に超え, OSHAの天井值としての許容濃度 20 ppm も超えていることがわかった。作業方法 によっても異なるが，八ウス開放が早い時期 で，空気のあおりを直接受けた場合には, NIOSH の IDLH である250ppm さえも超える 可能性がある。高知県は臭化メチル薰蒸後は 1 週間から10日はハウスを開放しないようにと指
導しているとのことであったが，現場ではそれ よりも早い時期にハウスを開放しており，その 際, 有効な保護具の着用状況も悪く, 課題が 残った。臭化メチルによる急性中毒事例11 15) は 今までにも数多く報告されてきたが，農業者が 依然として今回のようなやり方で薰蒸作業を行 う限り, 急性曝露に伴う中毒事例が発生する可 能性はあると考える。日本薰蒸技術協会などが 
安全な薰蒸方法のしおり ${ }^{16)}$ 配布しているが， 現場ではあまりいかされていないようである。

今回のアンケート調査から，農業者が実際に 使用している臭化メチルの使用量は行政の指導 している範囲内（10アール当たり20〜30kg） を遥かに超えていた。臭化メチルが有害化学物 質である以上, 適切な使用量で薰蒸作業が行わ れるべきである。農業者の健康障害を予防する という産業保健の立場からいえば, 使用する臭 化メチルの量が減れば, 気中濃度も減少するは ずであり, 当然のこととして, 個人曝露量も減 少する。

ハウス開放翌日のパイプ配管作業時に数十 $\mathrm{ppm}$ の臭化メチルが環境モニタリングで観測 されたが, その際の個人曝露測定では臭化メチ ルを確認できなかった。これは，今回用いた環 境モニタリングのシステムが臭化メチルのメチ ル基に注目して分析しているため，ハウス開放 後には土中で臭化メチルが微生物等の作用で化 学反応して，メチル基を有する化学物質を気中 に放出しているためと考える。しかし, 翌日の 作業で土を触れる農業者が皮膚から臭化メチル を吸収する危険性がまだ残されており，今後の 検討課題として残った。

臭化メチルの毒性は急性影響として呼吸器や 粘膜の刺激症状を中心として頭痛, めまい, 悪 心, 嘔吐, 昏睡, 痤攣, 歩行失調, 慢性影響と して下肢の異常感覚や失調性歩行など多彩な精 神神経症状などがよく知られている7,17,18)。今 回のアンケート調查での有訴状況を見ても, 眼 や呼吸器への刺激症状を訴えるものが数\%存在 しており，臭化メチルの一時的な曝露による影 響が伺える。その他，歩きづらいや手足が痺れ る，言葉が話しづらいなどの神経症状を訴える ものも $2 \%$ 程度観察された。これらの神経症状 が臭化メチル曝露に伴う慢性症状なのか, 加齿命 現象ないしは他疾患によるものなのかは今回明 らかにしえなかった。農業者が高齢である場合 には，臭化メチル曝露に伴うものであることを 自覚しないケースがあるといわれており, 今後 の検討課題として残った。

より安全な薫蒸作業を行うための対策とし
て，まず，農業者に対して，臭化メチルの安全 な扱い方法, 毒性などの教育, 急性曝露時の処 置などを十分に周知した上で，単位面積当たり の必要最低限度の使用量及びハウス開放のやり 方，保護具の着用など適切な薰蒸方法を行うよ うに心がけるべきである。当面は，行政ないし は農協等の販売者がこれらの指導にあたるべき であろう。今後, より安全な方法であると考え られているマルチ薫蒸方法についても, 環境モ ニタリングや個人曝露測定などを検討し，より 安全な薰蒸方法が農業者に提供されるべきであ ろう。さらには, 臭化メチルがオゾン層破壊物 質として全廃される方向で検討されていること を考慮すると，長期的には，臭化メチルに代わ る安全な代替化学物質が開発され, 現場に提供 されることが環境保健の立場からみても理想的 である。

\section{V. ま と め}

高知県は農業県であり, 園芸農業が活発であ るため, 臭化メチルを用いた薰蒸作業は日常的 に行われてきた。その意味では, 農業者は臭化 メチルを過去数十年間取り扱ってきた経緯があ り, 安全に対する警戒心の薄れなどから, 現場 での薰蒸作業には過剰な臭化メチルの使用や有 効な保護具の未着用などの多くの問題点が認め られた。現状の薰蒸作業では, 短時間で高濃度 の臭化メチルに曝露する危険性があるため, 農 業者への安全な作業方法を周知徹底する必要が ある。

\section{謝辞}

本研究は平成 9 年度臭化メチル等の環境挙動の把握 と削減・代替技術に関する研究（環境庁）の一環とし て実施されたものである。また, 今回の調查研究を行 うにあたり，アンケート調査項目に適切なご助言を頂 いた, 原一郎 (前関西医科大学教授) 先生と, 臭化メ チルの個人曝露測定に協力して頂いた, 熊谷信二（大 阪府立公衆衛生研究所労働衛生部) 先生に深謝いたし ます。

\section{文献}

1 ) 高知県農林水産部. 高知県の園芸. 高知: 高知県, 1993.

2 ) 総務庁統計局. 事業所統計報告, 第 2 巻都道府県 
編，その39 高知県. 東京：総務庁統計局, 1992 ; $78-89$.

3 ）労㗢省安全衛生部労衝衛生課編. 新衛生管理一法 令編 (第 1 種用). 東京: 中央労働災害防止協会, 1997 : 206-230.

4 ) 労㗢省安全衛生部労衝衛生課編. 特定化学物質等 作業主任者テキスト. 東京 : 中央労働災害防止協 会, 1997：53-55.

5 ）和田 功編. 産業保健マニュアル（第 3 版）. 東京： 南山堂, $1995 ; 210$.

6）宮野美宏７ 7.2.5法規などに基づく特殊健康診断， 現代労衝衛生ハンドブック (三浦豊彦ら編)。川 崎: 労働科学研究所, $1988 ; 1070-1100$.

7 ）産業医学振興財団. 化学物質による中毒一ガス中 毒一. 東京：産業医学振興財団, $1991 ； 40-50$.

8 ）労働省安全衛生部労衝衛生課編. 新衛生管理一管 理編 (第 1 種用). 東京: 中央労働災害防止協会, $1997 ; 104-143$.

9) ACGIH (American Conference of Governmental Industrial Hygienists). 1998 TLVs and BEIs. Cincinnati : ACGIH, 1998.

10) CDC (Centers for Diseases Control and Prevention). NIOSH Pocket Guide to Chemical Hazards. (DHHS Publication No. 94-116). Cincinnati: NIOSH, 1994.
11）荒記俊一, 阿部 彰, 牛尾耕一, 他. メチルブロ マイド中毒例の臨床的研究 (第 1 報)。日災医誌 $1970 ; 18: 447-457$.

12) Araki S, Ushio K, Abe A, et al. Methyl bromide poisoning: A proposal for a new clinical classification and the results of its application to fiftyseven cases so far reported in Japan. 産業医学 $1971 ; 13: 419-425$.

13）佐藤重仁，渡辺 徹，仲田充雄，他. 急性臭化 チル中毒. 救急医学 $1980 ； 4 ： 1673-1679$.

14）西岡和恵，浜中すみ子，藤田英輔. 土壌薰蒸剤（臭 化メチル）による化学熱傷の 1 例. 皮有 1982 ; $19: 247-248$.

15）石津澄子, 長尾憲樹, 山野優子, 他. 臭化メチル 中毒の 5 例について. 労働科学 $1988 ; 64(2): 72$ -80 .

16）石津澄子編. 臭化メチル中毒一中毒の予防と管理. 東京：日本薰蒸技術協会, 1988 .

17）若月俊一. 20.1.4健康障害. 現代労働衛生ハンド ブック (三浦豊彦ら編). 川崎 : 労働科学研究所, $1988 ; 1525-1531$.

18）荒記俊一，横山和仁. E. 1. 臭化メチル，臨床中毒 (井村裕夫ら編). 東京：中山書店. 1994；187190. 


\title{
A Study on Risk Assessments of Soil Fumigation with Methyl Bromide in Greenhouses
}

\author{
Shigeki KODA* and Hiroshi OHARA*
}

In order to protect farmers from health hazards posed by soil fumigation with methyl bromide in greenhouses, the authors monitored the concentrations of the fumigant inside greenhouses, before and after fumigation and measured occupational exposures. In the meantime, a questionnaire survey was conducted to find out the facts about working conditions, health effects and personal protective equipment in 1996.

As environmental concentrations of methyl bromide decreased from $2200 \mathrm{ppm}$ to $1100 \mathrm{ppm}$ gradually in three days, two farmers were exposed to $57 \mathrm{ppm}$ and $25 \mathrm{ppm}$, in opening up the greenhouses, respectively, which are above ACGIH's TLV-TWA (1ppm) and OSHA's PEL-C (20ppm). The questionnaire survey $(n=164)$ found that about $80 \%$ of the respondents have fumigated inside the whole greenhouse without mulch, above $90 \%$ have opened up greenhouses within 5 days, and that only $10 \%$ have worn effective gas masks and clothes. Regarding subjective symptoms after fumigation, $2 \% \sim 6 \%$ of respondents complained about eye and respiratory tract irritation.

These results suggest that farmers might be exposed to high concentrations of methyl bromide in opening up greenhouses. In order to prevent health hazards of methyl bromide, education programs on toxic information and health effects of methyl bromide, and safety training in soil fumigation should be provided to farmers.

* Department of Public Health, Kochi Medical School 